Check for updates

London, UK

Cite this as: $B M J 2020 ; 370: m 2689$ http://dx.doi.org/10.1136/bmj.m2689 Published: 06 July 2020

\section{Declarations of pharma funding to doctors are hit by covid-19 crisis}

\author{
Lynn Eaton
}

In an unexpected consequence of the covid-19 crisis, full annual data showing how much funding NHS staff and bodies receive from the pharmaceutical industry ${ }^{1}$ is unlikely to be available until at least the end of the year.

The news comes as another blow to attempts to increase transparency around payments made to NHS healthcare professionals and organisations, which totalled over $€ 538 \mathrm{~m}$ (€595m; \$671m) in 2019.

Campaigners, including The BMJ, have long fought for this information to be made public. In 2016, the Association of British Pharmaceutical Industries (ABPI) began publishing its annual Database UK, a summary of pharmaceutical companies' spend.

This is normally updated in June, but, as a result of the covid-19 crisis, the ABPI has only been able to publish data on how much individual drug companies spent in the past year and not who it has gone to.

"Under normal circumstances, we would write to more than 20000 NHS professionals and organisations that industry works with to ask them to verify their data ahead of publication," said Sheuli Porkess, director of research, medical, and innovation at the ABPI.

"We could not send out these requests at the time when the clear priority for the NHS was to tackle the pandemic.”

The ABPI can't confirm a timescale for publication but hopes it will be by the end of the year. "We are mindful of the possibility of a second wave of covid-19, and winter pressures," said Porkess.

The data published in June only covers how much was spent on payments towards research and development (the bulk of funding) and towards attendance at conferences or sponsoring events. The research and development spend shows a slight increase from 2018 to 2019, up from £377m to £381m. An additional £157m went on sponsoring events and paying for attendance at conferences, including travel. This compared with £126m in 2018.

The decision to publish in this limited format comes after long standing criticism about the way the data are collated and presented. ${ }^{2}$

One critic, Piotr Ozieranski, lecturer at the department of social and policy sciences, University of Bath, accepted the difficulties relating to the pandemic. Nonetheless, he said, the ABPI database could have been improved by having unique identifiers for payment recipients, shared by all drug companies.

"With these, it might be possible to calculate the accurate number of recipients for healthcare professionals and organisations. This would allow us to see the extent to which certain healthcare professionals or organisations receive funding from different companies or are funded exclusively by specific companies.

"Another would be to include information on specific products linked to the payments, as is the case in the US Open Payments database.”

A spokesperson for the ABPI said, "We're always looking to improve the usability of Disclosure UK so suggestions are welcome."

The ABPI said it was reviewing its code of practice for 2021. The proposals include additional requirements for patients and journalists to declare funding from pharmaceutical companies from $2022 .^{3}$

\footnotetext{
ABPI. Disclosure UK. www.abpi.org.uk/our-ethics/disclosure-uk.

Mulinari S, Ozieranski P. Disclosure of payments by pharmaceutical companies to healthcare professionals in the UK: analysis of the Association of the British Pharmaceutical Industry's Disclosure UK database, 2015 and 2016 cohorts. BMJ Open 2018;8:. doi: 10.1136/bmjopen-2018-023094 pmid: 30344175

3 Prescription Medicines Code of Practice Authority. ABPI consultation on the proposed 2021 ABPI code of practice. www.pmcpa.org.uk/the-code/abpi-consultationon-the-proposed-2021-abpi-code-of-practice.
}

This article is made freely available for use in accordance with BMJ's website terms and conditions for the duration of the covid-19 pandemic or until otherwise determined by BMJ. You may use, download and print the article for any lawful, non-commercial purpose (including text and data mining) provided that all copyright notices and trade marks are retained. 